\title{
Kurdish-Canadian Identity and the Intricacies of Acculturation
}

\author{
Abdurrahman Wahab ${ }^{1}$ \\ University of Toronto, Canada
}

\begin{abstract}
This paper studies the process of acculturation of the Iraqi Kurdish community in Ontario, Canada. It examines factors that impact the adaptation of a dual identity, such as ethno-cultural identities and socio-cultural circumstances. The study explores components of the Kurdish participants' ethnic and national identities, including their self-identification, sense of belonging, and participation in aspects of life. It also elaborates on the ways in which members of the Iraqi Kurdish community in Canada understand and construe their life experiences, and what it means to live as Kurdish immigrants in a multicultural society.

Keywords: Kurdistan, dual identity, acculturation, Kurdish-Canadian, Iraqi Kurdish, self-identification.
\end{abstract}

\section{Introduction and Rationale}

According to the 2016 Canada population census, the total number of Kurds in Canada is 16,315 (Statistics Canada, 2017). Yet, there have been very few studies on this population. When the matter of critical studies of Kurds in Canada emerged, these studies unfortunately essentialized communities and failed to theorize their 'heterogeneity, hybridity, and multiplicity' (Lowe, 1996). A recent study on the effect of cultural difference on mental health in refugees and new immigrants includes the Kurds in a sample of youth from "16 different ethno-cultural groups" in Canada (Beiser, Puente-Duran, \& Hou, 2015, p. 37). However, it refers to Kurds as a single cultural group and does not give them their particular voices. Rather, this study reinforces a monolithic description of Kurdish diasporas. Two other studies on the Kurdish community in Canada understand the Kurdish community as comprised of the Kurds coming from the different states of the Middle East where the majority of the Kurdish populations reside, such as Turkey, Iraq, Syria, and Iran (Peralta, 1997; Sciortino, 2000). Both of these works take a similar approach in conducting an ethnographic study of some aspects of the Kurdish ethnic identities in Canada, such as language, culture and history, and the way these components influence the political aspects of the Kurdish identity (Peralta, 1997), and the genesis of the Kurdish community and its mobilization within Canadian politics (Sciortino, 2000). Even though the authors of these studies refer to the fact that the Kurdish community in Canada is not culturally homogenous, they still assume that the Kurdish ethnic identity is unified, static, and mainly contained by the Kurdish language and other visible cultural elements rather than constructed by a dynamic interchange of different socio-cultural identities and circumstances. There is more to the construction of ethnic identity than traditional cultural markers, since, as Phinney, Horenczyk, Liebkind, and Vedder (2001) state, "Ethnic identity is a dynamic construct that evolves and changes in response to developmental and contextual factors" (p. 496). Two other studies specifically examine the Kurds from Iraq (Gardner, Polyzoi, \& Rampaul, 1996; Miraftab, 2000). Gardner, Polyzoi, and Rampaul (1996) deal with individual variables that influenced the progress of immigrants from Iraqi Kurdistan and Bosnia who arrived in Manitoba in 1992 in ESL programs. Miraftab (2000) particularly examines the obstacles that Somali and Iraqi Kurdish new immigrants and refugees living in Metropolitan Vancouver face when it comes to access to housing.

Evident from the brief literature review above, there is a significant lack of research on the conditions of the Kurdish community in Canada, particularly those from the Iraqi Kurdistan Region. Such studies are especially significant because the Kurdistan Regional Government (KRG) is the only Kurdish official entity with which the Canadian government has foreign relations on a diplomatic level. In 2014 the Canadian government opened a Canadian Trade Representation Office in Erbil city, the capital of the Kurdistan Region, which was "Canada's first trade mission to Iraq in 25 years" (Government of Canada, 2014). Furthermore, the Kurdish armed forces in Iraq have been an effective force in combating ISIS, and Kurdish politics has been a major player in the Iraqi political scene. It is also significant to note that the political situation and the socio-cultural impact of the Kurdish people from Kurdistan Region differ from those of the other Kurds. A major aspect of this difference is related to the fact that the Iraqi Kurds have been running their social, political and cultural affairs with relative autonomy since 1992. Furthermore, in 2005 , the

\footnotetext{
${ }^{1}$ He received his $\mathrm{PhD}$ in Social Justice Education and Educational Policy from the Ontario Institute for Studies in Education at the University of Toronto, Canada. Correspondent email: abdu.wahab@alum.utoronto.ca
} 
Iraqi constitution recognized Iraq as a federal state and the areas under the administrative control of the Kurdistan Regional Government as a federal province. The people of Kurdistan Region, with their different ethnic and religious affiliations, have been running the government and shaping its official cultural and political identities for over two decades. Hence, Kurdistan Region, a quasi-independent province within the state of Iraq is an official entity representing the people of the Region who comprise not only the Kurds, but also other ethnic groups such as the Assyrians, the Chaldeans and the Turkomans (Ala'Aldeen, 2013; Bengio, 2012; KNA, 2015; Natali, 2005; Stansfield, 2005; Stansfield, 2003). Unlike the Iraqi Kurds, the Kurds from North Kurdistan, West Kurdistan, and East Kurdistan are seen in the official political discourses simply as marginalized minorities within the Turkish, Arabic and Persian nation states.

\section{Purpose and Scope}

This paper explores the process of acculturation of the Iraqi Kurdish community in Ontario, Canada and their adaptation of a dual identity of being Kurdish-Canadian. It examines factors that impact the adaptation of a dual identity, such as the ethno-cultural identities and socio-cultural circumstances. The study explores components of the ethnic and national identities of the Kurdish participants from Ontario, Canada, such as their self-identification, sense of belonging, and participation in aspects of life comprising their dual identity. Even though these components are presented in much of the literature as aspects of ethnic identity (Phinney, 1990), they are used in this study to also understand the status of the participants' national identity, with specific emphasis on their Canadian identity. There is extensive literature on ethnic and social identities and intergroup behavior (Phinney et al., 2001; Dion \& Phan, 2009; Tajfel, 1974; Phinney, 1990, 2004; Phinney, Jacoby, \& Silva, 2007; Ong, Fuller-Rowell, \& Phinney, 2010), acculturation and adaptation in diverse and immigrant societies (Berry, 1997; Berry, Phinney, Sam, \& Vedder, 2006; Phinney et al., 2001), transborder and dual citizenships (Schiller, 2005; Khayati, 2008), multiculturalism in Canada (Ghosh, 2004; Berry, 2013), and immigration and the issues of social cohesion (Holtug, 2010; Holtug \& Mason, 2010; Cheong, Edwards, Goulbourne, \& Solomos, 2007). The existence of this literature provides valuable theoretical and methodological support in understanding the ethnic and national identities of the Iraqi Kurdish community and the process of acculturation and adaptation they undergo within multicultural Canada.

Specifying the Iraqi Kurdish community in this study is an attempt to show the dynamic aspect of the Kurdish ethnic and national identities and to avoid essentializing their political, social and cultural markers. As I previously mentioned, unlike others, the Iraqi Kurds have been running a quasi-state with its modern structures and bureaucracy for over two decades, which has given them greater control over their cultural, social and political identities. To understand processes of acculturation and the formation of identities among the Kurdish populations worldwide, this work examines the 'Kurdish nation' beyond historically shared visible linguistic and cultural aspects and includes the socio-political and socio-economic demarcations, such as state policies and legislations, that play a significant role in shaping ethnic and national identities (Anderson, 2006; Eriksen, 2010; Gellner, 1983). As Phinney (1990) states, "the task of ethnic identity is complicated, because the uniqueness that distinguishes each group makes it difficult to draw general conclusions" (p. 499). It is uncritical to draw general conclusions about the Kurds and assume a uniformity in their ethnic and national identities. Hence, the purpose as well as the significance of studying the Kurdish community

from the Kurdistan Region in isolation from the larger Kurdish population in Canada is twofold: one, to avoid simplistic assumptions and general conclusions on the social, cultural and national Kurdish identities; and two, to expand the scope of the Kurdish identity to include not only the Kurds but also to the peoples living on the land of Kurdistan. This latter point particularly signifies the political, social and cultural relationships, overlaps and dissolutions that different ethnic groups can develop vis-à-vis the Kurdish-run KRG and its modern state structures.

\section{Conceptual Framework}

In order to better understand how the Kurdish community from the Iraqi Kurdistan Region is involved in the process of acculturation and adaptation of a dual identity in Ontario, Canada, I use a conceptual framework that considers acculturation as a complex process of 'intercultural contact' whereby cultures undergo different levels of change when they are in direct contact with each other (Berry, 1997; Lafer \& Tarman, 2019; Woofter, 2019). The process of acculturation is influenced by "the interaction between the attitudes and characteristics of immigrants and the responses of the receiving society, moderated by the particular circumstances of the immigrant group within the new society" (Phinney et al., 2001, p. 494). In this sense, two major aspects of acculturation are the "preservation of one's heritage culture and adaptation to the host society" (Phinney et al., 2001, p. 495). In an immigrant community of a culturally plural society, positively undertaking these aspects of acculturation means that immigrants are considered to have engaged in a process of integration. Within this conceptual framework, when immigrants go through this process, they do not have to "give up their culture of origin in order to adapt to the new society," but as they adopt aspects of the host culture, they become bicultural (Phinney et al., 2001, p. 495). 
The present study takes the meaning of ethnic identity as "an individual's sense of self in terms of membership in a particular ethnic group" with various aspects, such as "self-identification, feelings of belongingness and commitment to a group, a sense of shared values, and attitudes toward one's own ethnic group" (Phinney et al., 2001, p. 496). Phinney et al. (2001) also define national identity to mean the identification that immigrants experience in their new society, which involves "feelings of belonging to, and attitudes toward, the larger society" (p. 497).

\section{Study Design and Sampling}

To answer the main research question, understanding the process of acculturation of the Kurdish community from the Iraqi Kurdistan Region in Ontario, Canada, I embarked on this study by designing a number of exploratory questions in order to examine how members of the Iraqi Kurdish community in Canada understand and construe their life experiences and what it means for them to live as immigrants in a multicultural society. I used a qualitative research methodology (Merriam, 2009) to allow for an in-depth investigation of participants' experiences and also to give them the opportunity to present their stories in a more detailed and descriptive way. A qualitative methodology also allows the researcher to deal with the data on a narrative level, providing more access to actions and experiences in order to tell the participants' stories in the best way (Merriam, 2009). To collect data for this study, I conducted direct, semistructured interviews using a mixture of open-ended, hypothetical, yes/no, and other combinations of questions in order to motivate detailed and elaborate responses from the participants. I found that the participants had some difficulty describing their cultural and ethnic identities in intense detail. This was mainly because I am from Kurdistan Region, so they talked with the assumption that their ethnic and cultural identities were obvious to me. I had to remind them that they were mainly speaking to a non-Kurdish audience who would probably not know much about Kurdistan Region and the Kurdish culture.

Using a purposeful sampling technique, I interviewed five people from Kurdistan Region, three males and two females, who were residents of Ontario, Canada. Choosing participants from Ontario was based solely on access to location. I conducted three interviews in Kurdish and two in English as per the comfort of the participants. Four of the interviews were conducted face-to-face and one via Skype ${ }^{\mathrm{TM}}$. Each interview ranged between one and two hours of casual discussion to allow each participant more time to reflect on his or her responses and insights. Even with a limited number of participants, I have tried to make sure that the participant sample reflects some aspects of the ethnic, religious and dialectal diversity of the Iraqi Kurdish community. The sample, which I formed through previous contact and snowball sampling, contains Kurds and non-Kurds, Muslims and non-Muslims, former residents of the major cities in Kurdistan Region, and first- and second-generation immigrants. However, it is significant to understand that the sample in this study by no means fully reflects the ethnic, social and cultural diversity of the Kurdish community in Kurdistan Region or in Canada. For the purpose of confidentiality I have used a pseudonym and given limited personal information for each participant.

\section{Analysis and Findings}

This section addresses each participant and highlights some of the key thematic components related to psychological acculturation. After presenting a brief description of each participant, I engage in the analysis using the conceptual framework as a lens to unpack how each participant negotiated and articulated their identity within the contexts of Iraqi Kurdistan Region and Canada.

The Kurdish participants show that their ability to self-identify as Kurdish-Canadians without social, cultural or political constraints has contributed to their acculturation. The significance of this is better understood when compared to the Iraqi Kurdish experience of restraint and national struggle in their home country for self-identification. Historically they have faced many obstacles and persecution for such self-identification, particularly in Iraq where this has manifested itself as a political struggle against acculturation into the Iraqi national Arab ethnic identity. I also noticed that the participants' self-identification comes out as interplay between their historical experiences related to their cultural identity in their homeland and their current and emerging experiences in Canada. Unique or otherwise, the participants' self-identification as Kurdish-Canadians is better understood when these experiences are put into the particular social, political and historical context of the Kurds in both the Iraqi and Canadian localities.

The self-identification of the Kurdish participants in the Canadian context also elaborates on the intricacies of their sense of belonging to the Canadian society. The participants express a strong sense of belonging to Canada while they still indicate a perseverance of their ethnic identity. What comes forward across the participants' experiences as new immigrants in Canada is that their ethnic, social and cultural identity as Kurdish does not compromise their belonging to the Canadian polity. The participants do not express any significant social or cultural conflicts between both sides of their ethnic and national dual identity. This strong sense of belonging to the Canadian nationality does not interfere with their Kurdish identity, which is in contrast to how the participants perceive their belonging to the 
Iraqi nationality. The participants' account of their belonging to the Canadian polity, in contrast to a lack in such sense towards their Iraqi nationality, sheds light on the discrepancy between citizenship in its mere legal terms and the extending social and cultural dimensions. Even though the participants are legally both Iraqi and Canadian citizens, their sense of belonging to both polities was not equally expressed; hence their 'dual' identity indicates an ethnic and a national identity rather than a dual citizenship.

\section{Self-Identification}

According to Dion and Phan (2009), as a result of government policy that supports and encourages multiculturalism in Canada, ethnic and cultural diversity at the societal level has become "one important component contributing to the vitality of Canadian society" (p. 49). Successful multicultural policy and practices result in immigrants having a sense of security as a member of the Canadian society, considering it valid and valuable to engage in processes of both the ethnic and national identities, supporting circumstances and creating environments in the society for contact among the diverse cultures (Berry, 2013; Etherington, 2019). This has contributed to the ethnic and cultural self-labeling of some components of the Canadian society. Through engaging the study participants with a number of questions about self-identification and discussing the reasons why they gave particular responses, it became clear that they strongly self-identified as having both Kurdish and Canadian identities.

\section{The Kurdish Identity}

Ethnic and/or cultural self-labeling is an important aspect of the multifaceted construct of ethnic identity (Dion \& Phan, 2009). One of the components of ethnic identity is the sense that one belongs to the specific ethnic or cultural group. Pashew, who first came to Canada along with his family in 1997, is originally from Erbil city. His ethnicity is not Kurd, and he is a Christian. We spoke in Kurdish throughout the interview, which lasted about two hours. He clearly emphasized the different aspects of his Kurdish identity. "I am a Chaldean, not a Kurd," he repeated several times throughout our discussions: "But I am a Kurdistani, from Kurdistan." The reason why he so strongly inclined to his Kurdish identity was that he defined his identity in connection to the culture of the Region, the history, and the connection of the people to the land:

We all look alike, both Christians and Muslims...We have the same marriage ceremonies, the same ways of farming, use similar language and terms; have similar traditions in clothes and food. When we prepare food, we know it is all from the same place.

Pashew's story is interesting, particularly when put within the context of the Kurdish liberation movement. $\mathrm{He}$ is a prominent member of one of the nationalist political parties in the Kurdistan Region. When I visited his house, I saw old photos of his parents, siblings and some relatives framed on the wall. During the 1980's, the dictatorship regime of Iraq executed them all as a way to force Pashew to surrender himself since he was a freedom fighter in the mountains. When I asked him why he became a member of a Kurdish nationalist party that is striving for the independence of the land of the Kurds (what the word "Kurdistan" literally means), he replied:

When we say Kurdistan, it is the land. Whoever lives on it is responsible to it. When disaster and hardship come, all get a share of it. This land is my birthplace, my grave. I grew up on it. All my family, parents and ancestors have lived on it. We have plowed this land, have planted seeds, and have sweated on it. We all have protected it without regard to who is Kurdish, Christian, or Muslim. The land is called Kurdistan, and I am from there.

Rasti is a Kurd originally from Kirkuk (which is outside the official KRG administration) with a background in Yârsân religion. He first came to Canada along with his family in 2002. He has a degree in engineering from Baghdad University, and works in Toronto as a Project Manager in a factory. He confessed that his "spirit of Kurdishness" has grown stronger since he left Kurdistan. When I asked him about what he meant by "spirit of Kurdishness," he said: "I love my Kurdish nationality. It is not that I don't care if I were an Arab, a Persian, or a Turk." He believes that because of the religion of Islam, the Kurds in Iraq share much of their thinking, customs and traditions with the Arabs, but the Kurds still have their own language and culture. He also referred to the distinctiveness of the geographical area: "In Iraq, the land where the Kurds live is different from the land where the Arabs live." While there is a focus on difference as an element of self-identification among the participants, it has become a unifying factor through which they present the sense of a national unity. Difference is spatialized through ethnicity unto the landscape. For Rasti, the Kurds are 
"a people who share the same pain, wronged by different Arab, Persian and Turkish regimes." Pashew also referred to the different regimes created by the Arabs in Iraq as oppressive:

I respect the Arabs, but their regimes have considered us enemies. When they bombed a city or a town, they never said to only bomb the Kurds. They have never made a difference between black, white or yellow. To the regimes, all were the same....all were the enemy.

Nergiz is a Kurdish girl from Duhok city who came to Canada in 1992 with her family when she was four years old. She does not remember much of her life prior to coming to Canada. She considers herself a second generation Kurdish in Canada. Like the other participants in this study, a major aspect of her Kurdish identity is her strong feeling towards the Kurdish struggle against assimilation particularly in recent history:

One of the big things that makes me not want to forget or lose my culture is because of our history and because of the fact that our people have faced attempts of assimilation by the other nations around us. Because when something is taken from you, it makes it much sweeter to you, to want to hold on to it and never allow any other type of influence to take it away.

Nergiz identified herself as equally Kurdish and Canadian. Even though the first time she visited Kurdistan was when she was nineteen years old, she grew up in Canada learning the Kurdish language in her big family of nine siblings, and a few other relatives, including aunts, uncles and cousins. She has been back to Kurdistan Region several times. She stayed there for two years teaching at an international school in Erbil city: "I have the influence of the Canadian culture as well as the Kurdish. For me it is like almost an equal balance." When I asked her about how she defines her Kurdish identity, she said:

It is my history and roots. It is something that I don't want to lose. Things like the language, understanding the history and the culture...I have a sense of pride in my culture...Culture, like the language, and the customs, like the traditional Kurdish dress, traditions, little things that you find specific to an area...Traditions like marriage, raising your kids, different celebrations, Nowruz, which is very very important to me.

Aram is a Kurd from Erbil city who immigrated to Canada in 1994. He is self-employed in a line of work that has many Kurdish and other customers from the Middle East. Aram considers himself a Kurd who has lived in Canada for a long time. When I asked him about what he meant by that, he said that he was a "Kurdish-Canadian." Elaborating further on what he meant by "Kurdish," he said: "Kurds are known by the land on which they live. The land is divided on four states. Kurdistan is our own land. I am from Kurdistan. I was born there." In response to my question about what makes the Kurdish identity distinct, he said that despite sharing much with the cultures of the other nations in the Middle East, Kurdish culture is made distinct by the traditional clothes and the language. He also mentioned that the land has mountains. "As a Kurd [in Canada], I have my ways and they are how I was brought up and lived in Kurdistan. I am what I have learned from my parents and from my background."

Nazdar is a Kurd from Sulaimani city. She lived in Europe as an immigrant in the early 1990's prior to immigrating to Canada in 1998 as a sponsored spouse. After our self-introductions, she let me know that she could express herself better in English. She immediately started talking about her memories of Kurdistan, particularly memories of Sulaimani city, which at a point brought tears to her eyes. I asked her what it meant for her to be a Kurdish living in Canada:

Well, first of all, I was born in Kurdistan, where it is my beginning. And my language is Kurdish, and the education. I was educated in Kurdistan from grade one to grade twelve...the first word I uttered was Kurdish. My first friend was Kurdish, and the whole environment was Kurdish...My real memories are in Sulaimani. They are so precious and it is always overwhelming when I talk about it. Those memories are the basis of whoever I am today.

For Nazdar, to be Kurdish means "to have an identity, a very clear identity. I don't have a lost identity...by lost identity I mean when you don't know where you belong." She also identified herself strongly with the Kurdish 
struggle for the right of self-determination and emphasized her sentiments with the Kurdish cause. She defined her Kurdish identity to be a significant aspect in the history of the Kurdish strives for independence: "They sometimes tell me that I have a strong personality. What does that mean? It is how you grow up. I didn't grow up with Barbie, I grew up with bullets, with problems, with prisons, with the news."

\section{The Canadian Identity}

It is evident that the participants strongly identify themselves as Kurdish, whether as an ethnic or a national identity, and the way they do so is very comparably articulated. Their self-identification as Canadian is also similarly articulated. All of them consider themselves Canadians, not only by having citizenship as a legal status, but also by the expressed feelings of belonging. However, the degree of strength varies in this aspect of their identity.

When I asked the participants about how much they considered their Canadian citizenship as part of their identity, they clearly expressed that they had a dual identity. The participants in this study believe in their Canadian identity and are happy about it. They consider having a dual identity as a positive thing, and their Kurdish and Canadian identities complement each other. The participants referred to the positive influence of multiculturalism on their selfidentification as Kurdish and also as Canadians. For the participants, multiculturalism seems to be a major reason for having strong feelings about both identities, as the government encourages different ethnic groups to celebrate and present their cultures. Pashew considers it his Canadian legal right to represent his Kurdish culture at national festivals or at particular Kurdish celebrations. Rasti sees that his self-identification as a Kurdish-Canadian is a duty: "Since I see that the government and the system here try to introduce different ethnicities to each other, then it is my duty to introduce my ethnicity and culture." Rasti sees Canada as a country of many cultures: "I feel proud of holding on to my identity and I am one of those many cultures of Canada. We are part of this Canadian culture. I feel great to be a Kurd in Canada." According to Rasti, there are some people who do not identify themselves with their ethnic origins and have told him that he does not need to say he is Kurdish. The fact that there is a significant Kurdish diaspora, especially from Iraq, and that he is one of the leaders at a Kurdish community center in Toronto, Rasti finds it significant to express his Kurdish identity but also to encourage others to do the same.

However, the participants gave different degrees of strength to their Canadian identity. Pashew, who already had family and children when he first immigrated to Canada, and Nergiz, who is a second generation Kurd, both said that they have a balanced dual identity. For Pashew, having a particular history with the Kurdish liberation movement, his current ties with a major political party in Kurdistan Region, and his active role in the Kurdish community in Canada have strengthened his Kurdish identity. On the other hand, he sees himself as fully integrated in the Canadian society:

I have a life with [the Canadians]. My children also work and study here. They are at a stage in their life where they have productions here. I have volunteered in the community. I have worked, paid taxes, and received taxes. I haven't participated in any vandalism, theft, or disturbances. I have even helped the police when my help was needed. I have voted in elections. I have done my obligations as a Canadian.

Also, based on her expression, Nergiz's identity is a balanced combination of Canadian and Kurdish identities. Almost all her life and education has been in Canada, and she has acquired her Kurdish identity from her family. Her Kurdish identity was strengthened even more by her later visits to the Kurdistan Region to a point where she has thought of going back and working there. She has also taken an academic track in her current education in Canada based on a future career in Kurdistan. Considering her strong ties with Kurdistan, the strength of the other side of her dual identity is also manifest in the way she expressed what it means to be Canadian:

To say that I am Canadian is a weird thing to define. Do you know what I mean? For me being Canadian means to be exposed to so many different cultures, meeting so many people from different parts of the world...the diversity...and not just the tolerance for it, but the celebration of the different cultures. I feel that a big aspect of my Canadian identity is to celebrate different cultures. Not just being proud of one, but being proud that we are a mosaic of different cultures not just one.

Aram introduced himself as a Kurdish-Canadian, yet considered his Canadian identity stronger. Aram expressed a few times that even though he had good relations with the Kurdish community, mostly through his work, he had less time to socialize with them because he worked six days a week. He started by saying that he liked being in Canada and that he had been here for a long time. I could see in the way he expressed his feelings about living in 
Canada that he had a strong sense of gratitude: "Canada took me in when my life and situation were very bad. That is why I never forget this. I consider Canada as my country." I asked about what made him a Canadian, he said:

As a Canadian, I have all the rights, the right to education, to vote in elections, to have representatives in the Parliament, everything. When you become a Canadian, that is it. I feel like a Canadian, there is no difference in any way.

However, Aram still makes sure that his children keep their Kurdish identity by taking them back to Kurdistan Region occasionally for a few months so that they acquire some of the Kurdish traditions and cultures. "I want them to know what uncle is, what aunt is...these are important," he explained. He also said that he liked his children to learn Kurdish, because one day when they grow up, they might like to live in Kurdistan, making it better that they know something about Kurds and Kurdistan.

Rasti and Nazdar both put their Kurdish identity first, while also expressing their integration with their Canadian identity. Rasti sees himself as a Canadian citizen, with all the rights that any Canadian has. But he still believes that his Kurdish identity comes first: "I look different from the real Canadians...the whites. When you don't look white and you are a new immigrant, your identity is not fully Canadian." For Rasti, to be a real Canadian means to behave like the white people, including an English accent like theirs. He admits that even though Canadian society is a very diverse society, whites are still dominant because of their number and because of racism too. He mentioned that there are specific lines of work in Ontario that are only for white people, such as the fire department and municipality workers. Rasti mentioned that he was made aware of his identity as being not a real Canadian when he was on a business trip to the United States, when in conversations with colleagues from the States, he was told that he did not look like Canadians: "I told them that I have a Canadian passport. They said "No, where are you originally from?' Why? Because they looked at my face. That's why I still don't have the feeling." Nonetheless, Rasti also said that in Canada he feels just like the next person. Nazdar also put her identity as a Kurd before her Canadian identity: "I am a Kurdish-Canadian, not a Canadian Kurd...I am one hundred percent a Kurd, I am an Iraqi." She came to Canada when she was in her mid-forties. So, as she said, she was "already metal-formed." However, she still considered her belonging to Canada strong, and her life and experiences in Canada were a continuation of what "I was brought up upon. Living in Canada only reinforced it." Nazdar, with a degree in Law from the University of Baghdad, is an immigration consultant in the Mississauga area. She is critical of those who only consider their citizenship as an easy ticket to a better life without holding much regard to what Canadian citizenship entails in terms of the responsibilities that come with it. She also expressed feelings of gratitude for her life in Canada and said, "I am holding the passport and the citizenship of Canada. Therefore, I am very proud of this. My citizenship is completely, totally, from A to Z is to respect this citizenship and give back whatever they give me."

\section{Sense of Belonging}

The participants' sense of belonging to Canada is better understood as a psychological acculturation (Berry, 1997), since, based on their accounts, not much has changed in their ethnic culture, while all of them present a strong sense of being Canadian citizens. This is particularly noteworthy because even though the participants are Iraqi citizens (with Iraqi nationality) they did not express any belonging to Iraq, except for Nazdar, who has spent a significant part of her life in Baghdad and comes from a mixed marriage of a Kurdish father and an Arab mother. Moreover, she works in an environment surrounded by the Iraqi diaspora. It is significant to understand that having a citizenship of a country in its legal sense does not always create a sense of belonging to the body politic in that country. This is especially true when components of the citizenry become the subject of constant exclusion and denial of rights based on ethnic and cultural identities, particularly when these identities are not considered part of the national identity (Schiller, 2005). The sense of belonging to Canada, however, continually came forward in the participants' accounts of their selfidentification. This is mainly because when immigrants to a new country obtain not only a new legal citizenship but also a cultural and social citizenship, their ethnic, social and cultural differences do not compromise their belonging to the polity (Schiller, 2005; Maira, 2009; Naber, 2012; Thangaraj, 2015).

None of the participants in this study expressed any significant social or cultural conflicts between both sides of their ethnic and national identity. Rather, when I asked them what it meant for them to be Canadian, they referred to the easiness for them to express their Kurdish identity, to be exposed to different cultures and be part of a rich cultural mosaic, have all the rights and accept the responsibilities that come with their citizenship. The participants expressed that being in Canada has strengthened their Kurdish identity. This is because, according to Rasti, when the surrounding is not Kurdish and the people are from other cultures and nationalities, presenting oneself as a Kurd becomes particularly important: "If I am in a more dominantly Kurdish community, I am less inclined to hold on to my Kurdish identity, because I feel that there is no pressure, no struggle, and I don't feel that I am different." Rasti 
also compared Canada with some European countries where some of his relatives live, and said that unlike those countries, Canada is multicultural. This has had a significant impact on his self-identification as a Kurd. Nergiz also felt that she had a stronger sense of Kurdish identity than her family in Kurdistan Region. One reason for this comes from the fact that growing up in Canada has made her miss out on aspects of the Kurdish identity, such as language and religion. She thinks that people in Kurdistan take such aspects of their identity for granted because these are part of their daily life and are less reflected on. Another reason for her strong sense of belonging to the Kurdish identity is that exposure and understanding of other cultures has given her a different perspective about other peoples and herself. Whereas in Kurdistan Region, according to Nergiz, people are shown other cultures mostly through popular media and compare them as lesser than Kurdish culture.

Living in a diverse society, therefore, has helped the participants in this study not only to hold on to their Kurdish identity but also develop a sense of belonging to Canada. Multiculturalism, however, is not the only reason for this. When I asked the participants about what made them want to be Canadian, they more or less similarly referred to aspects of the system of life in Canada. Peshew, Rasti and Aram mentioned the equality of all citizens before the law, and that the law has guaranteed their rights as citizens regardless of their ethnic identity or of whether or not they have patronage from powerful people to be able to work. Also, all the participants mentioned freedom as an important factor that has strengthened their sense of belonging to Canada. Nergiz mentioned that as a Canadian citizen, freedom to practice whatever religion she wanted was important for her. She also mentioned freedom of expression, whether in criticizing the government and politicians or in dressing in a particular way. Aram mentioned the freedom to do whatever one wants "as long as it is not against the law." He also mentioned the freedom to travel and go around the country without any problems. Nazdar considered the freedom of speech and ideas as important indicators of life in Canada. Pashew saw Canada as a country where there is the freedom to work anywhere one wants regardless of gender differences: "If my daughter was fourteen and worked at Tim Hortons ${ }^{\circledR}$, it would have been normal." He also believes that those from the Kurdish community who have gone through Canadian education are more likely to give more freedom to their families, and if they go back to Kurdistan as teachers, they would give more freedom to their students. Rasti also pointed to the freedom of speech and expression, and mentioned that he could take any kind of job without affecting his reputation.

The participants also pointed to their happiness with the systems of education and healthcare, and considered them important in their life in Canada. For them, Canadian education can have a significant impact on their dual identity and can strengthen the Kurdish community in Canada. According to Nazdar, education is very important for the Kurdish community in Canada, because "instead of being an uneducated and unprofessional Kurd in Canada and lost between whether you are a Kurd or a Canadian, education makes it smoother and you become a better Kurd and a better Canadian." For many Kurdish families living in Canada, the education of their children is a major reason why they do not go back to Kurdistan Region. Rasti mentioned that in recent years most families who have returned to Kurdistan Region have been those whose children were either very young or have gone to college or have graduated: "People like me whose children are on their way to the university don't go back. Because education here is much better." A major reason why Aram and his family do not go back to live in Kurdistan Region is the education of his children. "Education in Canada is good. The schools are clean. The classes are taught well. Teachers are faithful to their classes. There is no discrimination among students...My children feel good in school here." Nergiz, who has lived almost all of her life in Canada, also considers the education system in Canada as a factor for her stay in Canada: "If I am married and have kids, then it would be better to live here. I don't think the health care system in Kurdistan is the best, and I would want my children to have a Canadian education." Pashew also considers the healthcare system a major reason why he stays in Canada.

I like to go back to Kurdistan and live there permanently, but I have a life, family and children who are established here. Also, at my age I need to take care of my health. The system here is very good.

For Nazdar, it is the system of life in Canada that defines her sense of belonging. "I feel that I belong to the system rather than to the society... and the system is very much different from the society." She relates this feeling to her life circumstances in Canada that is mostly surrounded by Kurdish and Iraqi people. However, she expressed feelings of regret that she still did not have "white Canadian people as friends. Because I want to learn more about this culture."

The participants' sense of belonging to Canada was also reflected in their participation in, affiliation to, or strong opinions about political life in Canada. Participation in elections was one point that most participants in this study mentioned. Rasti and Pashew stated that they are members of the Liberal Party. While Nazdar clearly stated that she was disappointed with the former Conservative government: 
Looking at it from my perspective as an immigration consultant, the influence, the rules and regulations and the things they are doing to immigration law have been detrimental to the system. Where is humanity in what Harper's government is doing by dropping the cases of three hundred thousand skilled workers after freezing them for five years, and they dropped them just like that, saying case closed...you are done? This is slaughtering. This is exactly what dictatorships are doing without regard to anybody. Do you think this is democracy? No.

Two factors have strengthened the sense of belonging to Canada, which comprises the participants' Canadian identity. On the one hand, it has been strengthened by the way the participants perceive their Canadian identity in relation to their Kurdish identity. On the other hand, it is bolstered by what their Canadian citizenship means to them in terms of their rights and responsibilities. As it is clear from the account of their self-identification, the Kurdish identity of the participants is very strong, and they refer aspects of this strength to their rights and obligations as Canadians to celebrate their Kurdish identity. For them, to be Canadian not only allows them to be Kurdish, but also strengthens their Kurdish identity. This is particularly important for the Kurdish people because, at least in their recent history, part of being Kurdish has been to hold on to their identity in the face of many attempts of assimilation and ethnic annihilation (Kaya \& Aydin, 2014; Kirmanj, 2013; Natali, 2005). Therefore, a strong element of the Kurdish identity is its association with the issues of basic human rights, freedom, dignity and equality before the law. The participants' emphasis on belonging to Canada in terms of what their Canadian identity means and their appreciation and integration into the system of life in Canada is fully intertwined with their perceptions of their Kurdish identity and struggle against assimilation. Nergiz elaborately pointed to the relationship between identity and a system of life that guarantees the basic human rights:

I think that the issue of Kurds in Iraq, and in other parts of the world, is an issue that has many factors involved, including both identity and human rights. I believe that the two factors go hand-in-hand. If we Kurds do not have our human rights (i.e., the right to choose which language we speak and teach our children, the right to cultural expression, the right to association and assembly, the freedom of press, the freedom of speech, and so on), then our identity will be affected as well. All of these rights are integral to our identity. Once these rights are denied and we become assimilated into the culture of the majority, we may potentially lose our Kurdish identity.

\section{Conclusion}

The participants' account of self-identification as Kurdish and Canadian and also the extent of their involvement in and their attitudes towards the Canadian life show that they are telling examples in the process of acculturation in Canada. They fluctuate in the strength that they give to each side of their dual identity have differing attitudes towards the components of their identities. The concept of acculturation is a complex process of interaction between both the ethnic and national identities, and since these identities are "conceptually distinct and can vary independently" (Phinney et al., 2001, p. 495), the variation in feelings that the participants show for their identities does not undermine their sociopolitical integration into Canadian society. This is particularly true when we see that all participants strongly and positively ascribe to their dual identity. It is also worth mentioning that the participants' selflabeling as Canadians is not reactive to an "imposed identity category," unlike their attitude towards their Iraqi nationality, thus it is more likely that they positively contribute to social cohesion (Dion \& Phan, 2009, p. 66). The participants do not feel pressure on their ethnic identity, and they therefore find it easier to integrate it with their Canadian identity. They do not see that any of these identities are threatened by one another. Rather, they have come to believe that these two identities strengthen each other.

\section{Acknowledgements}

I would like to acknowledge, first and foremost, the participants in this study who agreed to dedicate their time and effort to tell their stories. I would also like to thank Professor James Ryan of the Department of Leadership, Higher and Adult Education at the Ontario Institute for Studies in Education (OISE) for his guidance and support in conducting this study. I also acknowledge the guidance and support that I have received from the faculty, students and staff of the Department of Social Justice Education at OISE, University of Toronto. 


\section{References}

Ala'Aldeen, D. (2013). Nishtimansazy w systemy farmanrewayetyi khomaly le haremy Kurdistan [Nation building and the system of self-governance in Kurdistan region]. Erbil, Iraq: Aras Publishing.

Anderson, B. (2006). Imagined communities: Reflections on the origin and spread of nationalism (Rev. ed.). London, UK: Verso Books.

Beiser, M., Puente-Duran, S., \& Hou, F. (2015). Cultural distance and emotional problems among immigrant and refugee youth in Canada: Findings from the New Canadian Child and Youth Study (NCCYS). International Journal of Intercultural Relations, 49, 33-45. doi: 10.1016/j.ijintrel.2015.06.005

Bengio, O. (2012). The Kurds of Iraq: Building a state within a state. Boulder, CO: Lynne Rienner Publishers, Inc.

Berry, J. W. (1997). Immigration, acculturation and adaptation. Applied Psychology: An International Review, 47(1), 5-68. doi:10.1111/j.1464-0597.1997.tb01087.x

Berry, J. W. (2013). Research on multiculturalism in Canada. International Journal of Intercultural Relations, 37, 663-675. doi: 10.1016/j.ijintrel.2013.09.005

Berry, J. W., Phinney, J. S., Sam, D. L., \& Vedder, P. (2006). Immigrant youth: Acculturation, identity, and adaptation. Applied Psychology: An International Review, 55(3), 303-332. doi: 10.1111/j.1464-0597.2006.00256.x

Cheong, P. H., Edwards, R., Goulbourne, H., \& Solomos, J. (2007). Immigration, social cohesion, and social capital: A critical review. Critical Social Policy, 27(1), 24-49. doi: 10.1177/0261018307072206

Dion, K. K. \& Phan, M. B. (2009). Ethnic group ties, inter-group threat, and ethnic self-identity. In J. G. Reitz, R. Breton, K. K. Dion, \& K. L. Dion (Eds.), Multiculturalism and social cohesion: Potentials and challenges of diversity (1st ed., pp. 49-67). New York, NY: Springer. doi:10.1007/978-1-4020-9958-8

Eriksen, T. H. (2010). Ethnicity and nationalism: Anthropological perspectives (3rd ed.). London, UK: Pluto Press.

Etherington, M. (2019). The Challenge with Educational Transformation. Journal of Culture and Values in Education, 2(1), 96-112. Retrieved from http://cultureandvalues.org/index.php/JCV/article/view/33

Gardner, S., Polyzoi, E., \& Rampaul, Y. (1996). Individual variables, literacy history, and ESL progress among Kurdish and Bosnian immigrants. TESL Canadian Journal, 14(1), 1-20. doi: 10.18806/tesl.v14i1.674

Gellner, E. (1983). Nations and nationalism. Oxford, UK: Basil Blackwell.

Ghosh, R. (2004). Public education and multicultural policy in Canada: The special case of Quebec. International Review of Education, 50(5-6), 543-566. doi: 10.1007/s11159-004-4685-9

Government of Canada. (2014). Canada opens new trade office in nothern Iraq [News release]. Retrieved from https://www.canada.ca/en/news/archive/2014/02/canada-opens-new-trade-office-northern-iraq.html

Holtug, N. (2010). Immigration and the politics of social cohesion. Ethnicities, 10(4), 435-451. doi: $10.1177 / 1468796810378320$

Holtug, N. \& Mason, A. (2010). Introduction: Immigration, diversity and social cohesion. Ethnicities, 10(4), $407-414$. doi: $10.1177 / 1468796810378318$

Kaya, I., \& Aydin, H. (2014). Pluralism, multiculturalism and bilingual education [Çoğulculuk, Çokkültürlü ve İkidilli Eğitim]. Ankara: Ani Press.

Khayati, K. (2008). From victim diaspora to transborder citizenship? Diaspora formation and transnational relations among Kurds in France and Sweden. Linköping, Sweden: Linköping University. Retrieved from https://www.mah.se/upload/forskningscentrum/mim/2009\%20seminars/khalid\%20khayati\%2011\%20mars. pdf

Kirmanj, S. (2013). Identity and nation in Iraq. London, UK: Lynne Rienner Publishers, Inc.

KNA. (2015). Law of protecting the rights of groups in Kurdistan-Iraq [Yasay parastiny mafy pekhatekan le Kurdistan'Eraq]. Erbil, Iraq: Kurdistan Region-Iraq.

Lafer, S., \& Tarman, B. (2019). Editorial 2019: (2)1, Special Issue. Journal of Culture and Values in Education, 2(1), i-v. Retrieved from http://cultureandvalues.org/index.php/JCV/article/view/34

Lowe, L. (1996). Immigrant acts: On Asian American cultural politics. Durham, NC: Duke University Press.

Maira, S. M. (2009). Missing: Youth, citizenship, and empire after 9/11. Durham, NC: Duke University Press.

Merriam, S. B. (2009). Qualitative research: A guide to design and implementation. San Francisco, CA: Jossey-Bass.

Miraftab, F. (2000). Sheltering refugees: The housing experience of refugees in metropolitan Vancouver, Canada. Canadian Journal of Urban Research, 9(1), 42-63. Retrieved from http://www.jstor.org/stable/44320598

Naber, N. (2012). Arab America: Gender, cultural politics, and activism. New York, NY: New York University Press.

Natali, D. (2005). The Kurds and the state: Evolving national identity in Iraq, Turkey, and Iran. Syracuse, NY: Syracuse University Press.

Ong, A. D., Fuller-Rowell, T. E., \& Phinney, J. S. (2010). Measurement of ethnic identity: Recurrent and emerging issues. Identity: An International Journal of Theory and Research, 10, 39-49. doi:10.1080/15283481003676226

Peralta, J. B. (1997). The Kurds in Canada: A question of ethnic identity (Master's thesis). Retrieved from 
https://www.collectionscanada.gc.ca/obj/s4/f2/dsk2/ftp04/mq22098.pdf

Phinney, J. S. (1990). Ethnic identity in adolescents and adults: A review of research. Psychological Bulletin, 108(3), 499-514. doi: 10.1037/0033-2909.108.3.499

Phinney, J. S. (2004). Ethnic identity: Developmental and contextual perspectives. Retrieved from http://citeseerx.ist.psu.edu/viewdoc/download?doi=10.1.1.477.1331\&rep=rep1\&type=pdf

Phinney, J. S., Horenczyk, G., Liebkind, K., \& Vedder, P. (2001). Ethnic identity, immigration, and well-being: An interactional perspective. Journal of Social Issues, 57(3), 493-510. doi: 10.1111/0022-4537.00225

Phinney, J. S., Jacoby, B., \& Silva, C. (2007). Positive intergroup attitudes: The role of ethnic identity. International Journal of Behavioral Development. doi:10.1177/0165025407081466

Schiller, N. G. (2005). Transborder citizenship: An outcome of legal pluralism within transnational social fields. In F. Von Benda-Beckmann, K. Von Benda-Beckmann, \& A. Griffiths (Eds.), Mobile people, mobile law: Expanding legal relations in a contracting world (pp. 27-50). Burlington, ON: Ashgate.

Sciortino, J. E. (2000). The genesis of an ethnic community: The case of the Kurds in Canada (Master's thesis). Retrieved from full\&object_id=33315\&local_base=GEN01-MCG02

Stansfield, G. (2003). Iraqi Kurdistan: Political development and emergent democracy. London, UK: Routledge.

Stansfield, G. (2005). Governing Kurdistan: The strengths of division. In B. O’Leary, J. McGarry, \& K. Salih (Eds.), The future of Kurdistan in Iraq (pp. 195-218). Philadelphia, PA: University of Pennsylvania Press.

Statistics Canada. (2017). Data tables, 2016 census: Immigration and ethnocultural diversity (Catalogue number 98400-X2016187). Retrieved from http://www12.statcan.gc.ca/census-recensement/2016/dp-pd/dt-td/Rpeng.cfm?TABID $=2 \& \mathrm{LANG}=\mathrm{E} \& \mathrm{~A}=\mathrm{R} \& \mathrm{APATH}=3 \& \mathrm{DETAIL}=0 \& \mathrm{DIM}=0 \& \mathrm{FL}=\mathrm{O} \& \mathrm{FREE}=0 \& \mathrm{GC}=01 \& \mathrm{GL}$ $=-$ $1 \& \mathrm{GID}=1341679 \& \mathrm{GK}=1 \& \mathrm{GRP}=0 \& \mathrm{O}=\mathrm{D} \& \mathrm{PID}=110528 \& \mathrm{PRID}=10 \& \mathrm{PTYPE}=109445 \& \mathrm{~S}=0 \& \mathrm{SHOWALL}$ $=0 \& \mathrm{SUB}=0 \&$ Temporal $=2017 \& \mathrm{THEME}=120 \& \mathrm{VID}=0 \& \mathrm{VNAMEE}=\& \mathrm{VNAMEF}=\& \mathrm{D} 1=0 \& \mathrm{D} 2=0 \& \mathrm{D} 3=0 \&$ D4 $=0 \& D 5=0 \& D 6=0$

Tajfel, H. (1974). Social identity and intergroup behavior. Social Science Information, 13(2), 65-93. doi: $10.1177 / 053901847401300204$

Thangaraj, S. (2015). "They said 'go back to Afghanistan"”: South Asian American basketball culture and challenging the "terrorist" stereotype. Amerasia Journal, 41(2), 25-46. doi: 10.17953/aj.41.2.25

Woofter, S. (2019). [Book Review]: Building Equity: Policies and Practices to Empower All Learners. American Journal of Qualitative Research, 3(1), 136-139. https://doi.org/10.29333/ajqr/5815 